Pesq. Vet. Bras. 37(9):937-940, setembro 2017 DOI: $10.1590 / \mathrm{S} 0100-736 \mathrm{X} 2017000900007$

\title{
Surto de leptospirose em bezerros criados em resteva de $\operatorname{arroz}^{1}$
}

\author{
Matheus de Oliveira Reis ${ }^{2}$, Rafaela A. Caprioli ${ }^{2}$, Cláudio João M. Laisse ${ }^{2}$, Lorena \\ L.B. Guimarães ${ }^{2}$, Caroline P. de Andrade ${ }^{2}$, Fabiana M. Boabaid ${ }^{3}$, Luciana Sonne $^{2}$ \\ e David Driemeier ${ }^{2 *}$
}

\begin{abstract}
Reis M.O., Caprioli R.A., Laisse C.J.M., Guimarães L.L.B., Andrade C.P., Boabaid F.M., Sonne L. \& Driemeier D. 2017. [Leptospirosis outbreak in calves maintained in a rice stubble field.] Surto de leptospirose em bezerros criados em resteva de arroz. Pesquisa Veterinária Brasileira 37(9):937-940. Setor de Patologia Veterinária, Departamento de Patologia e Clínica Veterinária, Faculdade de Veterinária, Universidade Federal do Rio Grande do Sul, Avenida Bento Gonçalves 9090, Prédio 42505, Porto Alegre, RS 91540-000, Brazil.E-mail: davetpat@ufrgs.br

Leptospirosis is an infectious disease caused by bacteria of the genus Leptospira, which affect domestic and wild animals, and also humans. From October to November 2014, in a rural property located in Glorinha, RS, where cattle were kept in the rice stubble, thirteen calves presented hemoglobinuria and apathy, nine of which died within less than 24 hours after the onset of clinical signs. Four calves were necropsied (A, B, C and D). Tissue samples were collected in 10\% formalin. Samples of kidney, liver and lung from calves B, C and D were sent for PCR analysis for 16S ribosomal RNA and the protein Lip 32 genes of Leptospi$\mathrm{ra}$. At macroscopic examination jaundiced mucosae and subcutaneous tissue, orange liver, and lungs with multiple petechiae, predominantly in cranial lobes, were observed. The thoracic cavity of calf A was filled with a reddish fluid. At microscopic examination, severe hemorrhage was observed in the lungs; in the liver there was moderate diffuse centrilobular hepatocellular necrosis and vacuolization, in addition to discrete periportal lymphocytic infiltrate. Discrete multifocal lymphoplasmocytic interstitial nephritis was observed in the kidneys. PCR analyzis resulted positive for calves B and D. The diagnosis of leptospirosis in the calves was based on epidemiological, clinical and pathological findings associated with positive PCR analysis. This study demonstrates the importance of investigation of the disease when young bovids are raised in flooded areas and have clinical signs of an acute septicemic disease.
\end{abstract}

INDEX TERMS: Acute leptospirosis, Leptospira sp., calves, ruminants, septicemic disease.

RESUMO.- A leptospirose é uma doença infecciosa causada por bactérias do gênero Leptospira, que afeta animais domésticos, selvagens e também humanos. De outubro a novembro de 2014, numa propriedade rural localizada

\footnotetext{
${ }^{1}$ Recebido em 9 de dezembro de 2016.

Aceito para publicação em 19 de março de 2017.

${ }^{2}$ Setor de Patologia Veterinária (SPV), Departamento de Patologia e Clínica Veterinária (DPCV), Faculdade de Veterinária (FaVet), Universidade Federal do Rio Grande do Sul (UFRGS), Av. Bento Gonçalves 9090, Bairro Agronomia, Porto Alegre, RS 91540-000, Brasil. * Autor para correspondência: davetpat@ufrgs.br

${ }^{3}$ Faculdade de Medicina Veterinária, Universidade de Cuiabá (Unic), Rua Itália s/n, Jardim Europa, Cuiabá, MT 78065-480, Brasil.
}

em Glorinha, RS, em que bovinos eram mantidos em resteva de arroz, 13 bezerros manifestaram hemoglobinúria e apatia, nove dos quais morreram em menos de 24 horas após o início dos sinais clínicos. Foram necropsiados quatro bezerros (A, B, C e D). Fragmentos de tecido foram fixados em formalina a $10 \%$. Amostras de rim, fígado e pulmão dos Bezerros B, C e D foram enviadas para análise de PCR para RNA ribossômico $16 \mathrm{~S}$ e a proteína Lip 32 de Leptospira. No exame macroscópico foram observados mucosas e tecido subcutâneo amarelados, fígado alaranjado, pulmões com múltiplas petéquias, predominantemente nos lóbulos craniais. A cavidade torácica do Bezerro A estava repleta de um líquido vermelho-escuro. 
À avaliação microscópica foi observada hemorragia acentuada nos pulmões; no fígado havia necrose e vacuolização hepatocelular centrolobular difusa moderada, além de infiltrado linfocítico periportal discreto. Nos rins observou-se nefrite intersticial linfoplasmocítica discreta multifocal. A análise por PCR teve resultado positivo para os Bezerros B e D. 0 diagnóstico de leptospirose nos bezerros foi baseado nos achados epidemiológicos, clínicos e patológicos, associados ao resultado positivo na PCR. Este estudo demonstra a importância da investigação da doença quando animais jovens são criados em áreas inundadas e têm manifestações clínicas de doença septicêmica aguda.

TERMOS DE INDEXAÇÃO: Leptospirose aguda, Leptospira sp., bezerros, ruminantes, doença septicêmica.

\section{INTRODUÇÃO}

A leptospirose é uma doença infecciosa causada por bactérias do gênero Leptospira, que acomete animais domésticos, silvestres e humanos (Ellis 1984, Draghi et al. 2011). Em humanos, a doença é endêmica em regiões tropicais com índices pluviométricos elevados e altos níveis de água subterrânea, com casos esporádicos em climas áridos e desertos (Dutta \& Christopher 2005). A enfermidade é transmitida por animais infectados através do contato direto ou indireto com urina contaminada (Levett 2001, Adler \& De la Peña Moctezuma 2010). A doença tem caráter ocupacional e afeta especialmente agricultores, trabalhadores de matadouros e médicos veterinários (Hartskeerl \& Ellis 2011). A severidade da doença em humanos varia de acordo com o sorovar de Leptospira envolvido, idade e competência imunológica do paciente (Adler \& De la Peña Moctezuma 2010).

A leptospirose é também uma doença importante em cães, sendo a quarta doença infecciosa mais letal para a espécie na região Central do Rio Grande do Sul (Fighera et al. 2008). Cães acometidos geralmente apresentam icterícia, hemorragia - principalmente nos pulmões, além de graus variados de lesões renais e hepáticas (Tochetto et al. 2012), sendo mais comum a infecção pelos sorovares Canicola e Icterohaemorrhagiae (Himani et al. 2013).

Na pecuária a doença tem grande importância por gerar perdas econômicas, principalmente, por causar problemas reprodutivos, como abortamento e infertilidade (Ellis 1984, Draghi et al. 2011). Bovinos são os principais reservatórios do sorotipo Hardjo, sendo este um importante agente causador de abortamentos na espécie, e podem ainda ser infectados por outros sorovares, como Pomona, Grippotyphosa e outros (Himani et al. 2013).

Herbívoros são importantes também na manutenção do agente no ambiente, visto que Leptospira sp. sobrevive melhor em urina alcalina (Adler \& De la Peña Moctezuma 2010). Casos de leptospirose aguda em bovinos são infrequentes (Draghi et al. 2011), sendo assim, o objetivo deste estudo é descrever os achados epidemiológicos e clinicopatológicos de um surto de leptospirose em bezerros criados em resteva de arroz no município de Glorinha, Rio Grande do Sul, Brasil.

\section{MATERIAL E MÉTODOS}

Foram necropsiados quatro bezerros (A, B, C e D); um foi encaminhado para necropsia no Setor de Patologia Veterinária da Universidade Federal do Rio Grande do Sul e três foram necropsiados em visita à propriedade, na qual foram também colhidos dados sobre a epidemiologia e achados clínicos da doença. Dois bezerros eram machos (Bezerros A e C) e duas fêmeas (Bezerros B e D). Fragmentos de órgãos e tecidos foram coletados e fixados em formalina $10 \%$, e amostras de rim, fígado e pulmão foram congeladas. Foi realizada citologia através de esfregaço do baço e do encéfalo para pesquisa de Babesia spp. e Anaplasma marginale. As amostras fixadas em formalina foram processadas rotineiramente para histopatologia, incluídas em parafina, cortadas a $3 \mu \mathrm{m}$ e coradas com hematoxilina e eosina (HE). Cortes histológicos dos rins foram submetidos à técnica de impregnação por prata (Warthin-Starry).

Fragmentos de rim, fígado e pulmão dos Bezerros B, C e D foram encaminhados para PCR para identificação de Leptospira sp. A técnica de PCR foi realizada conforme o protocolo descrito por Ahmed et al. (2012), que desenvolveram uma técnica de PCR multiplex para Leptospira 16S RNA ribossomal e Leptospira patogênica pelo gene da proteína Lip 32, usando 200mM de dNTP, 1,5mM $\mathrm{MgCl} 2,10 \mathrm{pmol}$ de cada primer, $1 \mathrm{x}$ tampão da enzima e $1 \mathrm{U}$ de Taq polimerase. Para a reação de PCR foram empregados 5 min a $95^{\circ} \mathrm{C}$, seguidos de 35 ciclos de $30 \mathrm{seg}$ a $95^{\circ} \mathrm{C}, 30 \mathrm{seg}$ a $58^{\circ} \mathrm{C}$ e $45 \mathrm{seg}$ a $72^{\circ} \mathrm{C}$ e uma etapa final de 5 min a $72^{\circ} \mathrm{C}$.

\section{RESULTADOS}

Uma propriedade rural localizada no município de Glorinha, estado do Rio Grande do Sul, Brasil, possuía um lote de 45 vacas e 39 bezerros Angus mantido em resteva (=palhada, restos culturais de lavoura) de arroz (Fig. 1). De outubro a novembro de 2014 adoeceram 13 bezerros, nove dos quais morreram. Além destes casos, três vacas abortaram, mas não foi informada a idade gestacional em que os abortamentos ocorreram. Os bovinos não eram vacinados contra leptospirose, uma vez que a doença ainda não tinha sido diagnosticada na propriedade. Os bezerros apresentaram hemoglobinúria, apatia e morte em menos de 24 horas após o início dos sinais clínicos. Os Bezerros A, B e C tinham 28 a 35 dias de idade e o Bezerro D tinha dois dias.

No exame macroscópico, a cavidade torácica do Bezerro A estava repleta de líquido avermelhado. Nos Bezerros A, B

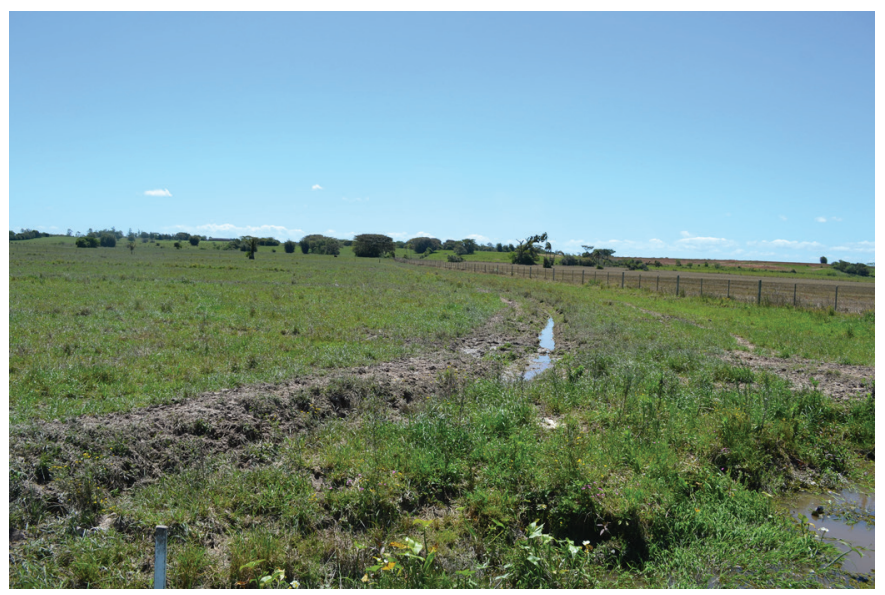

Fig.1. Leptospirose em bezerros criados em resteva de arroz (palhada ou restos culturais de lavoura) de arroz com áreas alagadiças em que estavam os bezerros afetados. 


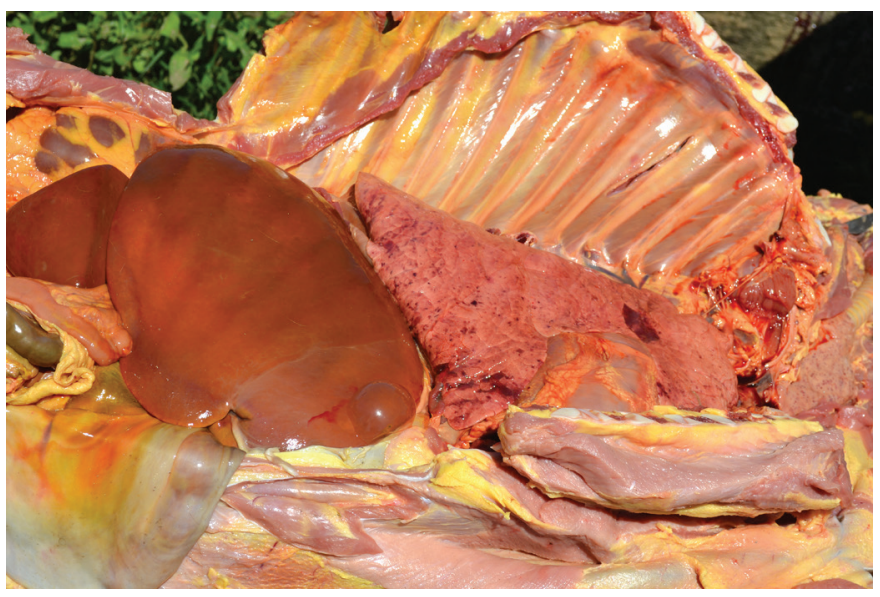

Fig.2. Leptospirose em bezerros criados em resteva de arroz. Necropsia do Bezerro B. Cavidades torácica e abdominal com serosas ictéricas, fígado alaranjado e hemorragias pulmonares multifocais.

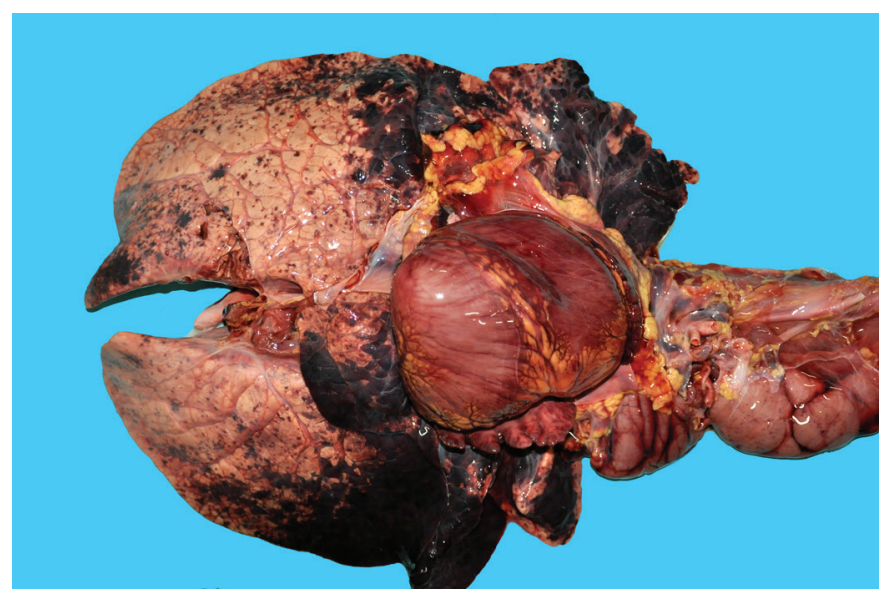

Fig.3. Leptospirose em bezerros criados em resteva de arroz. Necropsia do Bezerro A. Pulmões com hemorragias multifocais a coalescentes, mais acentuadas em lobos craniais.

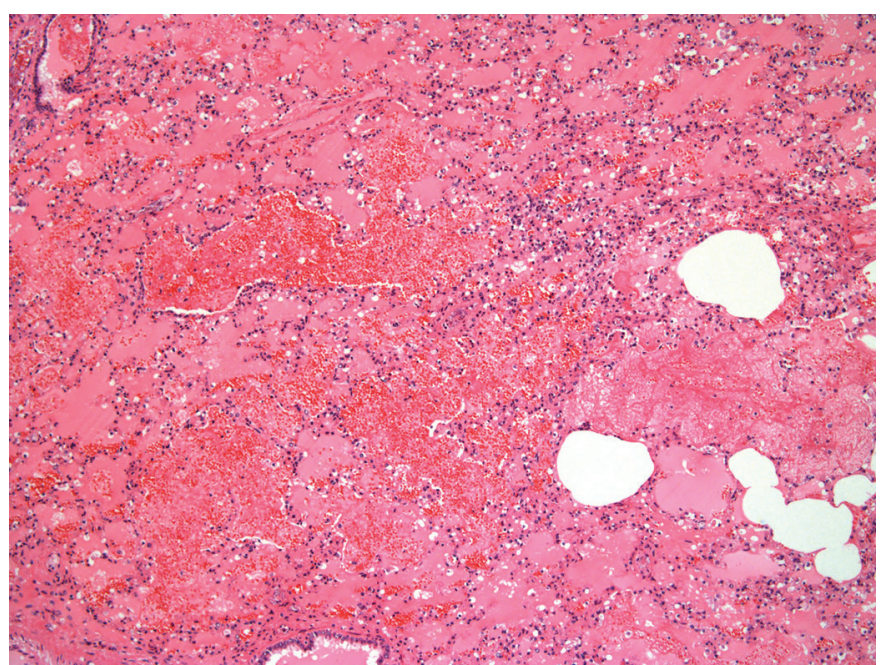

Fig.4. Leptospirose em bezerros criados em resteva de arroz. Avaliação histológica dos pulmões, demonstrando hemorragia acentuada associada à deposição multifocal de fibrina e edema difuso acentuado nos alvéolos. HE, obj.10x. e C foram observadas mucosas, tecido subcutâneo, cavidade torácica e abdominal ictéricas, fígado alaranjado (Fig.2), pulmões com hemorragias multifocais a coalescentes, localizadas predominantemente em lobos craniais (Fig.3). No timo, no intestino delgado e no intestino grosso havia hemorragias multifocais na serosa; os rins estavam difusamente avermelhados e com hemorragias multifocais. 0 Bezerro D tinha pequena quantidade de sangue na porção ventral do abdômen; diafragma e pulmões com múltiplos focos hemorrágicos e encéfalo discretamente congesto.

À avaliação microscópica foram observadas hemorragia e deposição difusa acentuada de fibrina nos pulmões (Fig.4), com espessamento discreto de septos alveolares e infiltrado discreto de linfócitos, macrófagos e raros neutrófilos. No fígado havia necrose e vacuolização hepatocelular centrolobular difusa moderada, além de infiltrado linfocítico periportal discreto, colestase intra-hepática difusa moderada e quantidade moderada de hemácias nucleadas intravasculares. Nos rins observaram-se cilindros hialinos em túbulos renais e nefrite intersticial linfoplasmocítica multifocal discreta. Em timo, intestino delgado e intestino grosso havia hemorragia multifocal discreta. Os esfregaços do baço e do encéfalo foram negativos para Babesia spp. e Anaplasma marginale. A técnica de Warthin-Starry resultou negativa para Leptospira sp.

No exame de PCR, os Bezerros B e D foram positivos para Leptospira 16S RNA ribossomal e para o gene da proteína Lip 32. 0 resultado do sequenciamento demonstrou 99\% de homologia com a sequência referência depositada no Genbank para os dois genes alvos.

\section{DISCUSSÃO E CONCLUSÃO}

O diagnóstico de leptospirose em bezerros foi baseado na epidemiologia, nos achados clínicos e patológicos associados à positividade na PCR. A atividade orizícola tem grande importância econômica no sul do Brasil e ocorre, muitas vezes, associada à prática da bovinocultura. Os bovinos são mantidos em palhadas de lavouras de arroz no período pós-colheita até o preparo do solo para a safra seguinte, ou durante o descanso da lavoura, que pode variar de um a dois anos (Marchezan et al. 2003). A produção de arroz é realizada em regiões alagadiças, em que o solo apresenta alta umidade, propiciando a sobrevida de bactérias do gênero Leptospira no ambiente (Levett 2001). 0 pH ótimo para a sua sobrevivência é próximo a neutralidade, entre 7,2 e 7,4 (Levett 2001, Girio \& Lemos 2007) e, em casos de terras destinadas ao plantio, há um maior controle do $\mathrm{pH}$ do solo, por meio da calagem, a fim de evitar solos muito ácidos (Marrenjo et al. 2016).

0 surto ocorreu na primavera, quando a temperatura no sul do Brasil está em elevação. A leptospirose é uma doença de caráter sazonal, com pico de ocorrência nas épocas de temperaturas mais elevadas (Levett 2001). Neste caso, o surto ocorreu em bezerros mantidos na resteva de arroz, enquanto que bovinos adultos mantidos na mesma área não apresentaram sinais clínicos de doença septicêmica, o que indica maior suscetibilidade dos bovinos jovens (Yeruham et al. 1997). Na mesma propriedade em que ocorreu o surto, outros bezerros mantidos em pastagens drenadas 
não foram acometidos. Em diferentes países, surtos de leptospirose em humanos estão associados a contato com água contaminada por urina de rato ou de bovinos, o que evidencia a importância do ambiente na propagação da doença (Levett 2001). Sendo assim, essas bactérias penetram no organismo através das mucosas ou pele umedecida por período prolongado, bem como por pequenos cortes (Adler \& De la Peña Moctezuma 2010).

Os achados clínicos e patológicos observados de hemoglobinúria, apatia e morte, com icterícia e hemorragia principalmente nos pulmões, são semelhantes aos descritos por outros autores (Yeruham et al. 1997, Draghi et al. 2011). Na infecção por Leptospira sp. as lesões resultam da liberação de toxinas bacterianas, com crises hemolíticas e septicemia, caracterizadas clinicamente por hemoglobinúria, anemia, hemorragias em mucosas e icterícia (Hunter 2004). 0 Bezerro $D$ tinha dois dias de idade, o que sugere infecção transplacentária, já que esta via de transmissão é comum em bovinos e o período de incubação varia de sete a 14 dias (Girio \& Lemos 2007). Três vacas abortaram. Os abortos possivelmente estavam relacionadas à infecção das vacas por Leptospira sp. pois o aborto é um dos principais problemas reprodutivos observados em bovinos adultos infectados (Draghi et al. 2011), no entanto, não foram feitos exames de fetos e dessas vacas para confirmação.

Esfregaços sanguíneos foram realizados a fim de descartar anaplasmose e babesiose, que também são causas de hemólise, anemia e icterícia, sendo que na Babesiose há também manifestação de hemoglobinúria. A técnica de impregnação pela prata (Warthin-Starry) resultou negativa, mas a doença não foi descartada, já que é comum apresentar resultados duvidosos nesta coloração (Tochetto et al. 2012).

Amostras de três dos quatro bezerros necropsiados foram encaminhadas para PCR, sendo dois com resultados positivo para Leptospira. 0 resultado negativo na PCR foi atribuído a possível degradação do DNA da amostra, vista a semelhança do quadro clinicopatológico com os demais casos.

Neste estudo foi diagnosticado um surto de leptospirose aguda em bezerros criados em resteva de arroz no sul do Brasil, o que torna pertinente investigar a doença quando bovinos jovens criados em locais alagadiços manifestam sinais de doença septicêmica de curso agudo. Estes achados reforçam a importância da necropsia, do exame histopatológico e da PCR para o diagnóstico de leptospirose.
Agradecimentos.- A todos que contribuíram de alguma forma para a elaboração deste trabalho.

Conflito de interesse.- Os autores declaram que não há conflitos de interesse.

\section{REFERÊNCIAS}

Adler B. \& De la Peña Moctezuma A. 2010. Leptospira and leptospirosis. Vet. Microbiol. 140:287-296.

Ahmed S.A., Sandai D.A., Musa S., Hoe C.H., Riadzi M., Lau K.L. \& Tang T.H. 2012. Rapid diagnosis of Leptospirosis by Multiplex PCR. Malays. J. Med. Sci. 19(3): 9-16

Draghi M.G., Brihuega B., Benítez D., Sala J.M., Biotti G.M., Pereyra M., Homse A. \& Guariniello L. 2011. Brote de leptospirosis en terneros en recría en la provincia de Corrientes, Argentina. Revta Argent. Microbiol. 43:4244

Dutta T.K. \& Christopher M. 2005. Leptospirosis: an overview. J. Assoc. Physicians India 53:545-551.

Ellis W.A. 1984. Bovine leptospirosis in the tropics: prevalence, pathogenesis and control. Prev. Vet. Med. 2:411- 421.

Fighera R.A., Souza T.M., Silva M.C., Brum J.S., Graça D.L., Kommers G.D., Irigoyen L.F. \& Barros C.S.L. 2008. Causas de morte e razões para eutanásia de cães da Mesorregião do Centro Ocidental Rio-Grandense (19652004). Pesq. Vet. Bras. 28:223-230.

Girio R.J.S. \& Lemos R.A.A. 2007. Leptospirose, p.331-347. In: Riet-Correa F., Schild A.L., Lemos R.A.A. \& Borges J.R.J. (Eds). Doenças de Ruminantes e Equídeos. $3^{\text {a }}$ ed. Pallotti, Santa Maria.

Hartskeerl R.A. \& Ellis W.A. 2011. Emergence, control and re-emerging leptospirosis: dynamics of infection in the changing world. Clin. Microbiol. Infect. 17:494-501.

Himani D., Suman M.K. \& Mane B.G. 2013. Epidemiology of leptospirosis: an Indian perspective. J. Foodborne Zoonotic Dis. 1(1):6-13.

Hunter P. 2004. Leptospirosis, p.1445-1456. In: Coetzer J.A.W. \& Tustin R.C. (Eds), Infectious Diseases of Livestock. Vol.3. 2nd ed. Oxford Press, Cape Town, South Africa.

Levett P.N. 2001. Leptospirosis. Clin. Microbiol. Rev. 14(2):296-326.

Marchezan E., Oliveira A.P.B.B., Avila L.A. \& Bundt A.L.P. 2003. Dinâmica do banco de sementes de arroz-vermelho afetado pelo pisoteio bovino e tempo de pousio da área. Planta Daninha 21(1):55-62.

Marrenjo G.J., Pádua E.J., Silva C.A., Soares P.C. \& Zinn Y.L. 2016. Impactos do cultivo por longo tempo de arroz inundado em Gleissolos. Pesq. Agropec. Bras. 51(8):967-977.

Tochetto C., Flores M.M., Kommers G.D., Barros C.S.L. \& Fighera R.A. 2012. Aspectos anatomopatológicos da leptospirose em cães: 53 casos (19652011). Pesq. Vet. Bras. 32(5):430-443.

Yeruham I., Bernstein M., Perl S., Irlin S., Cohen A., Yacobson B. \& Machnai B. 1997. Clinical and epizootiological study of a leptospirosis outbreak due to Leptospira canicola in a feedlot. J. S. Afr. Vet. Assoc. 68:105-107. 